\title{
Effects of drainage on the botanical richness of peat grassland
}

\author{
A. J. van Strien ${ }^{1}$ and Th. C. P. Melman ${ }^{2}$ \\ ${ }^{1}$ Department of Environmental Biology, University of Leiden, P.O. Box 9516, \\ 2300 RA Leiden, Netherlands \\ ${ }^{2}$ Centre for Environmental Studies, University of Leiden, Netherlands \\ Received 18 June 1986; accepted 9 February 1987
}

Key words: botanical richness, drainage, peat grassland

\begin{abstract}
The botanical richness of peat grassland is known to decrease after drainage and subsequent intensification of grassland exploitation. It is not known whether both events are responsible for this decrease. If intensive exploitation is less detrimental to the botanical richness when it is not preceded by drainage, omitting drainage would be preferable for the sake of nature management. To assess the separate effects of drainage on the botanical richness of peat grassland the original data of three previously executed studies were re-analysed. The results indicate that on extensively used grasslands the drainage alone has already great negative effects on botanical richness. On more intensively exploited grasslands only effects of nitrogen supply were found and no substantial drainage effects. This implies that omitting drainage seems to have hardly any advantage for the botanical richness when the intensification of exploitation goes on.
\end{abstract}

\section{Introduction}

Drainage of peat grassland by lowering the ditch water level has been carried out in a considerable number of areas in the Netherlands. For many peat regions drainage is considered to be desirable from an agricultural point of view, especially because drainage facilitates intensification of the grassland exploitation (Schothorst, 1982).

The drainage practice is disputed by nature conservationists. There is ample evidence that the drainage of extensively used, wet nature reserves often results in a decrease of the botanical value of the grassland vegetation (as expressed in the number of species or several other indices). This is attributed to a higher mineralization of peat and sometimes also to a reduced supply of calcium-rich seepage (Grootjans, 1985; Vermeer, 1985).

On agriculturally exploited grasslands the botanical richness also decreases after drainage (de Boer, 1982). However, drainage practice of farming-land is usually 
followed by intensification and it is not well known which effects are due to the drainage and which to the subsequent intensification.

From a point of view of nature management it is important to distinguish between these two causes. If the drainage itself has negative effects on the botanical richness, it will be attractive to search for possibilities for intensification without drainage.

There has been some research on the separate effects of drainage on the vegetation of agriculturally used peat grasslands (cf. Boxem \& Leusink, 1978). In these studies only the agricultural aspects of the botanical composition were emphasized. We re-analysed the original data of these studies to assess the separate effects of drainage on the botanical richness.

\section{Material and methods}

The separate effects of drainage can only be assessed if the drainage is an independent variable in the study. Therefore we only used studies in which effects of other variables are not important or can be corrected for statistically. We restricted ourselves to the studies that mainly concerned agriculturally exploited peat (or clayon-peat) grasslands in the typical peat districts of Noord-Holland, Zuid-Holland, Utrecht and Friesland.

Furthermore the complete botanical data had to be available. The following three studies fulfilled these conditions:

- the study of de Vries (Kruijne et al., 1967)

- the PAW970 study (van Steenbergen, 1976)

- the Zegveld study of Boxem \& Leusink (1978)

We will first give a short description of these studies.

\section{The study of de Vries}

This study was mainly performed between 1940 and 1955 . De Vries compared the vegetation of a large number of permanent grasslands in the Netherlands. These fields differed in soil type, soil moisture, type of land use and in phosphate and potassium content. The moisture status was estimated on the basis of a general impression of each field, including height of the ditch water level. These ditch water levels varied from about $0-10 \mathrm{~cm}$ to about $80 \mathrm{~cm}$ below the ground level. Type of land-use varied from extensively managed pure hayfields and hay pastures to more intensively exploited alternate pastures and pure pastures. Nitrogen supply has not been determined, but we assume that type of use and nitrogen application were closely related and that the nitrogen supply ranged from about $0 \mathrm{~kg} \mathrm{ha}^{-1}$ (pure hayfields) to about $100-150 \mathrm{~kg} \mathrm{ha}^{-1}$ (pure pastures) (van Burg et al., 1980). The grassland vegetation was sampled as described by de Vries (1937): on each parcel about 100 samples of $25 \mathrm{~cm}^{2}$ were taken.

In a review of their results Kruijne et al. (1967) compared the botanical composition of the different moisture classes without correcting for other factors. However, because of correlations between several factors the separate influence of soil moisture on the botanical richness of peat grassland cannot be deduced rightly from 
their publications (see also Elberse et al., 1983).

To meet this problem we re-analysed their data. We only used data of peat grasslands of Noord-Holland, Zuid-Holland, Utrecht and Friesland and discarded data of salt fields. This selection provided us with 130 appropriate grassland fields.

\section{The PAW970 study}

This study was carried out during the period 1964-1973. Both peat and clay-on-peat grassland fields in Zuid-Holland were involved; on each soil type three 'wet' fields and three fields with 'normal' moisture content were considered. The ditch water levels of the wet fields and of the normal fields were about $30-35$ and about $60 \mathrm{~cm}$ below the surface level respectively. Average water-tables from September to February were about 20 and $40 \mathrm{~cm}$ below surface and from March to August about 35 and $55 \mathrm{~cm}$ below surface (van Steenbergen, 1976).

All experimental fields were intensively used alternate pastures. On each field plots of $30 \mathrm{~m}^{2}$ were set out with a $\mathrm{N}$ application of 0,200 or $500 \mathrm{~kg} \mathrm{ha}^{-1}$. In addition, all plots were manured with about $50 \mathrm{~kg} \mathrm{~N} \mathrm{ha}^{-1}$. Phosphate and potassium contents were applied to keep up with the nitrogen supply.

Biomass contribution of all plant species of each plot were determined annually. Because long-term effects are especially interesting, we left out the data of the first three years of this experiment in order to eliminate the adaptation period of the vegetation.

\section{The Zegveld study}

This study was performed in the period 1970-1975 on an experimental farm of 30 ha on peat soil in Zegveld (Boxem \& Leusink, 1978; Schothorst, 1982). Unlike the studies described above the effects of experimental drainage were studied. In half of the farm area the ditch level was lowered to $75 \mathrm{~cm}$ below the surface level and in the other half a ditch level of $25 \mathrm{~cm}$ was adjusted. Ditch levels were maintained at these levels throughout the year.

After the drainage the pastures with high and with low ditch level were managed in exactly the same way until 1974. Nitrogen supply was about $400 \mathrm{~kg} \mathrm{ha}^{-1}$ (fertilizer and manure together) on all pastures. We only used data of 1970-1973. Because the ditch levels were established in 1969 , only short-term effects of drainage can be deduced from this study. Biomass contribution of the plant species were determined annually. We used data of all parcels except for a few parcels that had been newly sown.

\section{Botanical composition}

We used the following conceptions of botanical richness of a grassland field.

- Number of plant species. Evidentiy, a shortcoming of this simple valuation is that all species are of equal value.

- Number of 'quality indicating species' ('q.i. species'). In the system described by Drijver \& Melman (1983) only plant species are counted that contribute to the quality of grassland from a point of view of nature management. This means that two groups of species are skipped: over-exploitation species (such as Poa annua and 
Stellaria media) and indifferent species, i.e. species that only occasionally occur in grasslands (such as Lamium purpureum).

- Floristic value as developed by Clausman et al. (1984). In this system each plant species is weighed according to its degree of rareness and to its rate of decline. The floristic value is determined by the valuations of all species present.

To check whether the botanical composition differs at different moisture levels we also examined the occurrence of some typical moisture- and drought-indicating species. To this end we chose the moisture indicators Alopecurus geniculatus, Glyceria fluitans and Phalaris arundinacea and the drought indicators Dactylis glomerata and Poa pratense (de Boer, 1965).

\section{Statistics}

By means of an analysis of variance (ANOVA; Nie et al., 1975) we examined whether the botanical richness significantly differed between moisture classes and between classes of other involved factors. Also two-way interaction effects were tested. Effects of the factors were assessed prior to interaction effects. Cell frequencies were not similar for data of de Vries and similar for data of PAW970. We did not use an ANOVA with data of Zegveld, because the exploitation was similar on all parcels of that study. The ANOVA also calculated means of the three measures of botanical richness per factor class. These means are corrected for effects of other factors involved.

\section{Results}

\section{Using the data of de Vries}

For all peat grasslands together the number of species, number of 'q.i. species' and floristic value significantly differed between moisture classes and between types of

Table 1. Results of ANOVA with several sets of data of de Vries. Number of species, number of quality indicating species and floristic value were used as dependent variables. $F$ values are given for each factor and for interactions.

\begin{tabular}{|c|c|c|c|c|}
\hline Data used & Factors & $\begin{array}{l}\text { Number of species } \\
F \text { value }\end{array}$ & $\begin{array}{l}\text { Number of 'q.i. species' } \\
F \text { value }\end{array}$ & $\begin{array}{l}\text { Floristic value } \\
F \text { value }\end{array}$ \\
\hline $\begin{array}{l}\text { All grasslands } \\
(n=130)\end{array}$ & $\begin{array}{l}\text { moisture } \\
\text { type of use } \\
\text { interaction }\end{array}$ & $\begin{array}{l}4.72^{* *} \\
8.33^{* *} \\
2.02\end{array}$ & $\begin{array}{c}4.22^{* *} \\
14.99^{* *} \\
1.20\end{array}$ & $\begin{array}{c}2.65^{*} \\
29.26^{* *} \\
0.74\end{array}$ \\
\hline $\begin{array}{l}\text { Pure hayfields } \\
\text { and hay pastures } \\
(n=72)\end{array}$ & $\begin{array}{l}\text { moisture } \\
\text { type of use } \\
\text { interaction }\end{array}$ & $\begin{array}{l}3.59^{*} \\
1.92 \\
3.09\end{array}$ & $\begin{array}{l}3.24^{*} \\
7.39^{* *} \\
1.54\end{array}$ & $\begin{array}{c}1.74 \\
32.76^{* *} \\
0.23\end{array}$ \\
\hline $\begin{array}{l}\text { Alternate and } \\
\text { pure pastures } \\
(n=58)\end{array}$ & $\begin{array}{l}\text { moisture } \\
\text { type of use } \\
\text { interaction }\end{array}$ & $\begin{array}{l}1.19 \\
0.22 \\
1.07\end{array}$ & $\begin{array}{l}1.29 \\
0.52 \\
0.41\end{array}$ & $\begin{array}{l}2.20 \\
0.14 \\
0.10\end{array}$ \\
\hline
\end{tabular}

${ }^{*} P<0.05$; ${ }^{* *} P<0.01$. 


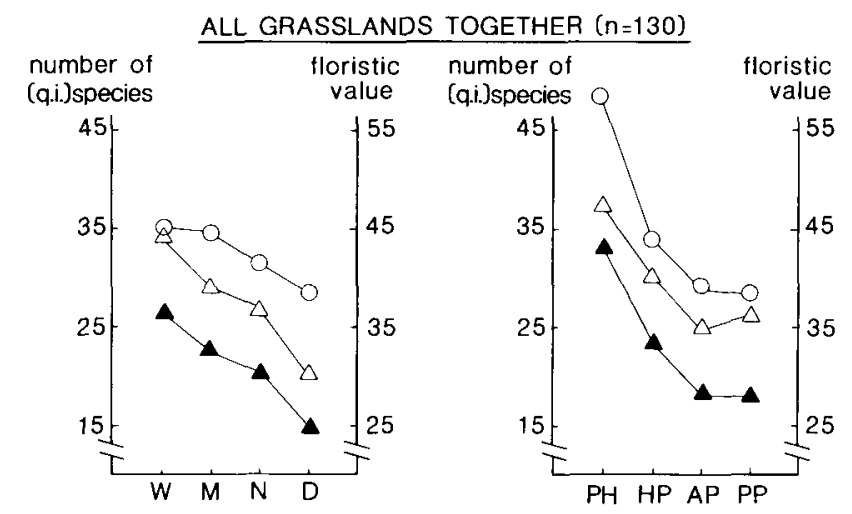

PURE HAYFIELDS and HAY PASTURES

ALTERNATE and PURE PASTURES

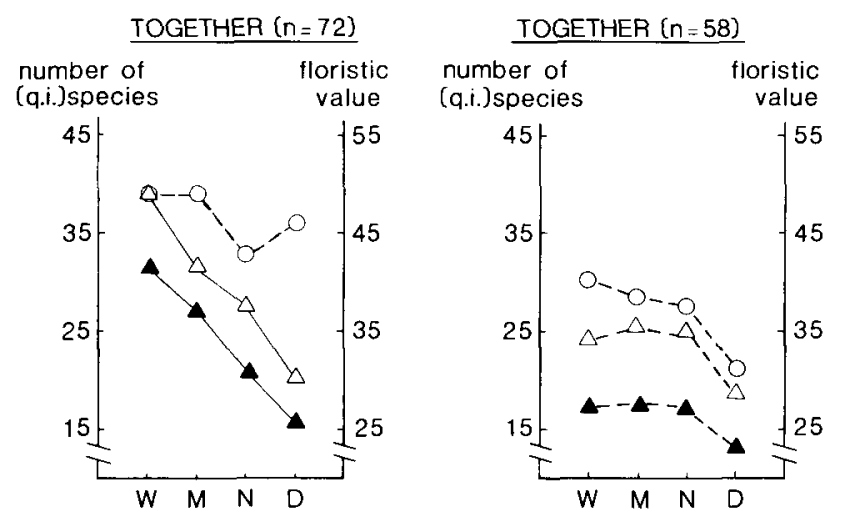

Fig. 1. Effects of the factors moisture and type of use on three measures of botanical richness based on data of de Vries. Class means of number of species $(\Delta)$, number of quality indicating species $(\boldsymbol{\Delta})$ and floristic value $(O)$ are given. These mean values are corrected for the effects of the other involved factor by means of ANOVA. ---- means: not significant. $W=$ wet; $M=$ moist; $N=$ normal; $D=d r y$. $\mathrm{PH}=$ p'sre hayfield $; \mathrm{HP}=$ hay pasture $; \mathrm{AP}=$ alternate pasture $; \mathrm{PP}=$ pure pasture.

use (Table 1; Fig. 1). The ANOVA indicates an almost significant interaction between the effects of moisture and type of use with respect to the number of species ( $F$ value $2.02 ; p=0.08)$. Therefore we repeated the ANOVA with two subsamples. For the extensively used pure hayfields and hay pastures together the number of species as well as the number of 'q.i. species' still significantly differed between moisture classes (Table 1; Fig. 1). These moisture effects are largely due to the effects among the most extensively used pure hayfields (Interaction $F$ value $=3.09$ with respect to the number of species; $p=0.08$ ). In contrast; for the more intensively exploited alternate and pure pastures together no such moisture effects were found (Table 1; Fig. 1).

Phosphate and potassium status did not differ between moisture classes per type 
of use (ANOVA; $p>0.10$ ). This suggests that the fertilization status of the moisture classes per type of use was equal.

\section{Using the PAW970 data}

Significant differences were found in botanical richness between nitrogen classes, but not between moisture levels (Fig. 2; Table 2). No differences were assessed between peat and clay-on-peat fields and no interactions were found between either factor (Table 2). In contrast with the measures of botanical richness the abundance of moisture- and drought-indicating species differed considerably between fields of different moisture classes (Table 3 ).
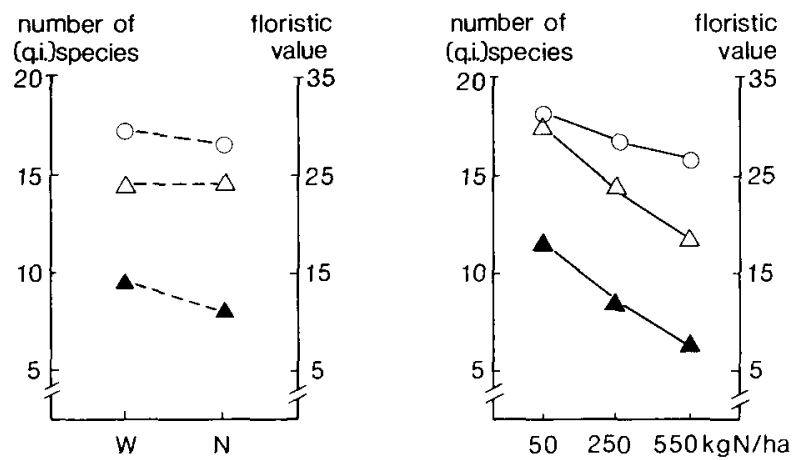

Fig. 2. Effects of the factors moisture and nitrogen supply (fertilizer application and manure together) on three measures of botanical richness based on data of PAW970. Class means of number of species $(\triangle)$, number of quality-indicating species $(\boldsymbol{\Delta})$ and floristic value $(O)$ are given. These mean values are corrected for the effects of the other factors involved by means of ANOVA. W $=$ wet; $\mathrm{N}=$ normal.

Table 2. Results of ANOVA with data of PAW970 $(n=36)$. Averages of number of species, number of quality indicating species and floristic value over the period 1967-1973 were used as dependent variables. $F$ values are given for each factor and for interactions.

\begin{tabular}{lccl}
\hline Factors & $\begin{array}{l}\text { Number of } \\
\text { species } \\
F \text { value }\end{array}$ & $\begin{array}{l}\text { Number of } \\
\text { cq.i. species' } \\
F \text { value }\end{array}$ & $\begin{array}{l}\text { Floristic } \\
\text { value } \\
F \text { value }\end{array}$ \\
Moisture & 0.07 & 3.57 & 1.75 \\
Nitrogen & $11.04^{* *}$ & $13.30^{* *}$ & $6.62^{* *}$ \\
Soil type & 0.57 & 0.04 & 1.67 \\
& & & \\
Interactions & & 0.53 & 0.05 \\
Moisture-nitrogen & 0.50 & 1.62 & 0.02 \\
Moisture-soil type & 0.02 & 0.23 & 1.29 \\
Nitrogen-soil type & 0.05 &
\end{tabular}


Table 3. Biomass contribution (\%) of moisture- and drought-indicating species on PAW970 and Zegveld plots. Each number represents the average of 18 plots with different nitrogen application and soil type over the period 1967-1973 (PAW970) or the average of 10 parcels over the period 1970-1973 (Zegveld).

\begin{tabular}{|c|c|c|c|c|}
\hline \multirow[t]{2}{*}{ Species } & \multicolumn{2}{|c|}{ PAW970 } & \multicolumn{2}{|l|}{ Zegveld } \\
\hline & wet & normal & high ditch level & low ditch level \\
\hline \multicolumn{5}{|l|}{ Moisture-indicating } \\
\hline Alopecurus geniculatus & 10 & 2 & 7 & 2 \\
\hline Glyceria fluitans & 8 & + & + & + \\
\hline Phalaris arundinacea & 1 & + & + & + \\
\hline \multicolumn{5}{|l|}{ Drought-indicating } \\
\hline Dactylis glomerata & + & 5 & + & + \\
\hline Poapratense & 1 & 3 & 3 & 5 \\
\hline
\end{tabular}

+ Less than $1 \%$.

Table 4. Botanical richness at high $(-25 \mathrm{~cm})$ and low $(-75 \mathrm{~cm})$ ditch levels in Zegveld. Each number represents the average and standard deviation of 10 parcels over the period 1970-1973.

\begin{tabular}{lcc}
\hline & High ditch level $(n=10)$ & Low ditch level $(n=10)$ \\
& $14.5 \pm 1.2$ & $14.0 \pm 1.3$ \\
Number of species & $7.1 \pm 1.1$ & $6.1 \pm 1.0$ \\
Number of 'q.i. species' & $26.0 \pm 1.4$ & $26.5 \pm 1.0$ \\
\hline
\end{tabular}

\section{Using the Zegveld data}

Neither the number of species nor the number of 'q.i. species' nor the floristic value differed significantly between moisture level classes of the Zegveld plots (Table 4; Wilcoxon test: $Q 14,45$ and 22 respectively; $p>0.05$ ). Differences in botanical composition during the first years after establishment of the ditch levels may still be too small to be detected. Therefore, we separately tested the differences in number of species, number of 'q.i. species' and floristic value in the fourth year (1973) after the start of the experiment. These differences were not significant either (Wilcoxon test: $\mathrm{Q} 7,19$ and 17 respectively, $p>0.05$ ).

Biomass contributions of moisture- and drought-indicating species are given in Table 3. Again Alopecurus geniculatus is more and Poa pratense is less abundant in wet than in dry plots. All other indicator species were scarce in both ditch level classes.

\section{Discussion}

The analysis of data of de Vries indicates that the effect of moisture on botanical richness depends on the intensity of exploitation. Among extensively exploited pure hayfields and hay pastures moisture effects are striking. Among the more intensively exploited alternate and pure pastures no significant moisture effects could be assessed. In the PAW970 and the Zegveld studies all fields were intensively 
managed. Both studies failed to show significant differences in botanical richness due to moisture differences, although the botanical composition varied with the moisture content, as appears from the occurrence of several moisture and drought indicators.

All three studies have certain shortcomings. The most notable one is the low number of plots involved, especially in the PAW970 study. A flaw of the study of de Vries is that the moisture status was estimated only once and in a rough way. A limitation of the Zegveld study is that it concerns only short-term drainage effects. Nevertheless it is evident from our analysis of the original data that drainage is detrimental to the botanical richness of extensively used agrarian grassland, even when it is not accompanied by intensification of exploitation. This agrees with the experiences in nature reserves (Grootjans, 1985; Vermeer, 1985). On intensively used grassland, on the other hand, drainage does not further reduce the botanical richness, suggesting that the effects of moisture are overshadowed by the effects of intensive exploitation. Thus in intensively used grasslands maintaining high ditch water levels is of no use to the aims of botanical nature management, unless it hinders the farmer from further intensification of exploitation.

\section{Acknowledgement}

We are grateful to Ing. Tj. Boxem (PR), Mr H. Mooi and the late $\mathrm{Mr}$ T. van Steenbergen $(\mathrm{CABO})$ for providing the original data. Thanks are also due to Drs $\mathrm{M}$. $\mathrm{M}$. Dorenbosch, Drs W. J. ter Keurs and Drs W. T. F. H. van Strien-van Liempt for critically reading the manuscript, to $\mathrm{Mr}$ J. Herzberg for preparing the figures and to Ms A. J. C. van der Niet for typing the manuscript. The research was supported by a grant from the Ministry of Agriculture and Fisheries, the Ministry of Housing, Physical Planning and the Environment and the Provincial Planological Service of Zuid-Holland.

\section{References}

Boer, Th. A. de, 1965. Grouping of regions on the basis of grassland vegetation. Netherlands Journal of Agricultural Science 13: 207-211.

Boer, Th. A. de, 1982. The use of peat soils for grassland. In: H. de Bakker \& M. W. van den Berg (Eds.), Proceedings Symposium on peat lands below sea level, p. 214-221. ILRI, Wageningen.

Boxem, Tj. \& A. W. F. Leusink, 1978. Ontwatering van veengrasland. Verslag van een vergelijkend onderzoek onder bedrijfsomstandigheden te Zegveld van $1970 \mathrm{t} / \mathrm{m} \mathrm{1975}$. Publikatie No 11, Proefstation voor de Rundveehouderij, Lelystad.

Burg, P. F. J. van, M. L. 't Hart \& H. Thomas, 1980. Nitrogen and grassland. Past and present situation in the Netherlands. In: W. H. Prins \& G. H. Arnolds (Eds.), The role of nitrogen in intensive grassland production, p. 15-33, Pudoc, Wageningen.

Clausman, P. H. M. A., W. van Wijngaarden \& A. J. den Held, 1984. Verspreiding en ecologie van wilde planten in Zuid-Holland. Deel A. Waarderingsparameters. Rapport, Provinciale Planologische Dienst Zuid-Holland.

Drijver, C. A. \& Th. C. P. Melman, 1983. Voorspelling en beoordeling van de effecten op de plantengroei van de in het IODZH te onderzoeken waterwinningsprojecten. Rapport No 19, Stuurgroep Integraal Onderzoek Drinkwatervoorziening Zuid-Holland. 


\section{DRAINAGE AND BOTANICAL RICHNESS OF PEAT GRASSLAND}

Elberse, W. Th., J. P. van den Bergh \& J. P. G. Dirven, 1983. Effects of use and mineral supply on the botanical composition on heavy-clay soil. Netherlands Journal of Agricultural Science 31: 63-88.

Grootjans, A. P., 1985. Changes of groundwater regime in wet meadows. Thesis, Department of Plant Ecology, University of Groningen.

Kruijne, A. A., D. M. de Vries \& H. Mooi, 1967. Bijdrage tot de oecologie van de Nederlandse grasplanten. Agricultural Research Reports 696, Pudoc, Wageningen.

Nie, N. H., C. Hadlai Hull, J. G. Henskins, K. Steinbrenner \& D. H. Brent, 1975. Statistical package for social sciences. McGraw-Hill, New York.

Schothorst, C. J., 1982. Drainage and behaviour of peat soils. H. de Bakker \& M. W. van den Berg (Eds.), Proceedings Symposium on peat lands below sea level, p. 130-163. ILRI, Wageningen.

Steenbergen, T. van, 1976. Het effect van stikstofbemesting op de gewasopbrengst van grasland bij diverse ontwateringstoestanden en grondsoorten. Verslag van de proefveldenserie PAW970, Deel II. Rapport, CABO, Wageningen.

Vermeer, J. G., 1985. Effects of nutrient availability and groundwater level on shoot biomass and species composition of mesotrophic plant communities. Thesis, Department of Landscape Ecology, University of Utrecht.

Vries, D. M. de, 1937. Methods of determining the botanical composition of hayfields and pastures. Report 4th International Grassland Congress (Great Britain), p. 474-480. 